\title{
Irony as an Impoliteness Tool: An Exploration of Irony's Intentionality, Cancellability and Strength
}

\author{
By Aikaterini Tselika*
}

\begin{abstract}
This paper studies the ways in which verbal irony can be used as an impoliteness tool. In the recent literature there has been an effort to define verbal irony and its uses, but very little or no study has been done on the impolite function of irony. My research will explore the cancellability of irony, its intentionality and examines the hypothesis that irony's strength can be either mitigated or enforced depending on the interlocutors' power differences. Furthermore, this paper will account for the various views on sarcasm and irony and propose that people resort to irony to make criticism as it does not make them sound rude or socially inappropriate. Situational, dramatic and positive ironies are not part of this study.
\end{abstract}

Keywords: Irony, Impoliteness, Politeness, Echoic Mention, Echoic Interpretation, Power, Dominance. Illocutionary/ Perlocutionary Force

\section{Introduction}

Politeness and impoliteness have received a lot of attention the last years in sociolinguistic studies, not only because there is still a lot of room for research in the aforementioned disciplines, but also because the subject of research, which is real conversations, sheds light on a variety of significant areas such as human cognition, human relationships and psychology. The reason I have chosen to explore irony in this paper is the fact that a comprehensive study on irony's impolite function is unaccounted for in the present literature and more significantly that its force on the hearer's future actions and/or his psychological state have been neglected.

Irony has been used inconsistently in the current literature, either as an umbrella term for all types of irony or interchangeably with sarcasm. In the section under the heading Literature Review, an effort is made to discern the different sub-types of irony (jocular irony, non-sarcastic irony, ironic sarcasm, sarcasm) and locate them in a continuum with different degrees of offensiveness. In the section under the heading Irony: A Convenient Impoliteness Tool, I propose over-politeness, the cancellability of irony, its intentionality and the attribution of self-containment to the speaker, as some of the reasons why speakers resort to irony when they want to make an impolite remark or to pass criticism instead of choosing a direct way.

In the section under the heading Strength of Criticism: How Much Does Irony Hurt?, I argue that irony is not necessarily a face-saving strategy according to politeness theories (Brown \& Levinson 1987), but has a face-

${ }^{*}$ Theoretical \& Applied Linguistics Mphil, Robinson College, University of Cambridge, UK. 
aggravating function as well in cases of interlocutors of unequal status. Finally, throughout the paper, I support the claim that irony's ability to balance between politeness, mock-politeness and impoliteness provides ample opportunities for future research.

\section{Aims of the Paper \& Methodology}

Irony has various uses such as for humorous purposes, fun, demonstration of wittiness, as also to make criticism which many times result in the interlocutor's discomfort, lack of confidence, insult and several other negative physiological states. But why does irony have a side which does good, such as jocular irony, and a side which hurts, such as sarcasm?

This study is mainly based on previous publications on irony and aims at 1) pinpointing the abilities of irony which gives it this dual role: to be used politely and impolitely and 2) to show that irony is not a face-saving strategy as is traditionally considered in the literature (Brown \& Levinson 1987) but as a face-aggravating strategy as well (Tselika 2014). Finally, 3) the main factor which is proposed to affect the strength of irony is the power difference between the interlocutors.

The exploration of irony is done theoretically by means of argumentation and criticism of previous studies and the limitations which arise make room for further research on the impolite function of irony. The examples which are used are from English and Greek language, taken either from the existing literature, or collected by means of note-taking through observation of authentic conversations, held in public places. Also, examples from movies are used, as acknowledged in the text.

\section{Literature Review}

There are several theories that provide an influential insight into what irony is, such as the following: the Leech's Irony Principle which is built upon his theory of Politeness Principle (Leech 1983, p.83); the Use-Mention Distinction (Wilson \& Sperber 1992, p.59; Sperber \& Wilson 1981); the Pretense Theory (Clark \& Gerrig 2007); the Allusional Pretense Theory (Kumon-Nakamura, Glucksberg \& Brown 2007); the Irony as Relevance Inappropriateness Theory (Attardo 2007); and the distinction of irony either as meaning-reversal or meaning-replacement (Kapogianni 2013,p.48-9). A detailed analysis of the views of each of the aforementioned theories falls beyond the scope of this paper which examines the impolite instances of irony in terms of their intentionality, cancellability and strength. I shall adopt the post Gricean views of irony as a particularized conversational implicature triggered, not only by the violation of the Quality maxim, as Grice initially claimed (Grice 1989,p. 34), but also by the violation of all maxims, as in the case of understatement (violation of Quantity Maxim): 
1. He is a little upset (said for someone very angry)

The traditional view that irony conveys the opposite of what is said has already been abandoned in the linguistic community (Haverkate 1990,p.82-4). Irony intends to communicate a message whose meaning is not necessarily the opposite of what is originally said ${ }^{1}$, but it could be a shift of its original meaning (Kapogianni 2013). Figure 1 shows Kapogianni's (2013) distinction of irony into non-sarcastic irony, ironic sarcasm and non-ironic sarcasm.

Figure 1. Non-Ironic Sarcasm/ Non-Sarcastic Irony

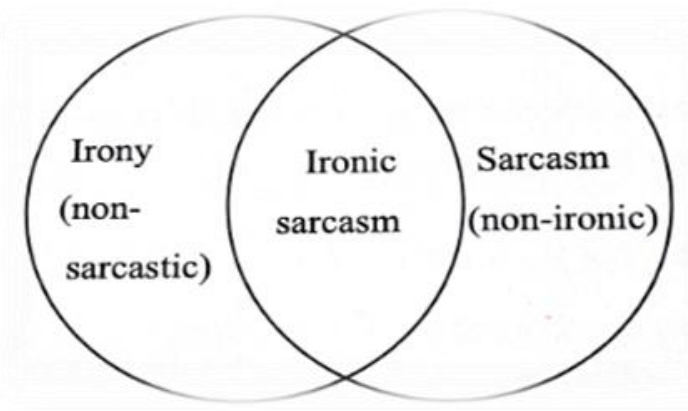

(Kapogianni 2013,p. 36)

The term irony has also been used in the literature inconsistently and many times is used interchangeably with sarcasm. This is why it is imperative to define the way irony is viewed in this study and provide a short description of its sub-types, one of which is sarcasm (Figure 2).

What actually makes irony such a special case is the fact that its different types carry different degrees of offensiveness which they balance between politeness and impoliteness. These types are: jocular irony, non-sarcastic irony, ironic sarcasm, non-ironic sarcasm. Figure 2 is adapted from Figure1 (Kapogianni 2013,p. 36) in order to accommodate jocular irony and humor.

Figure 2. Sub-types of Irony

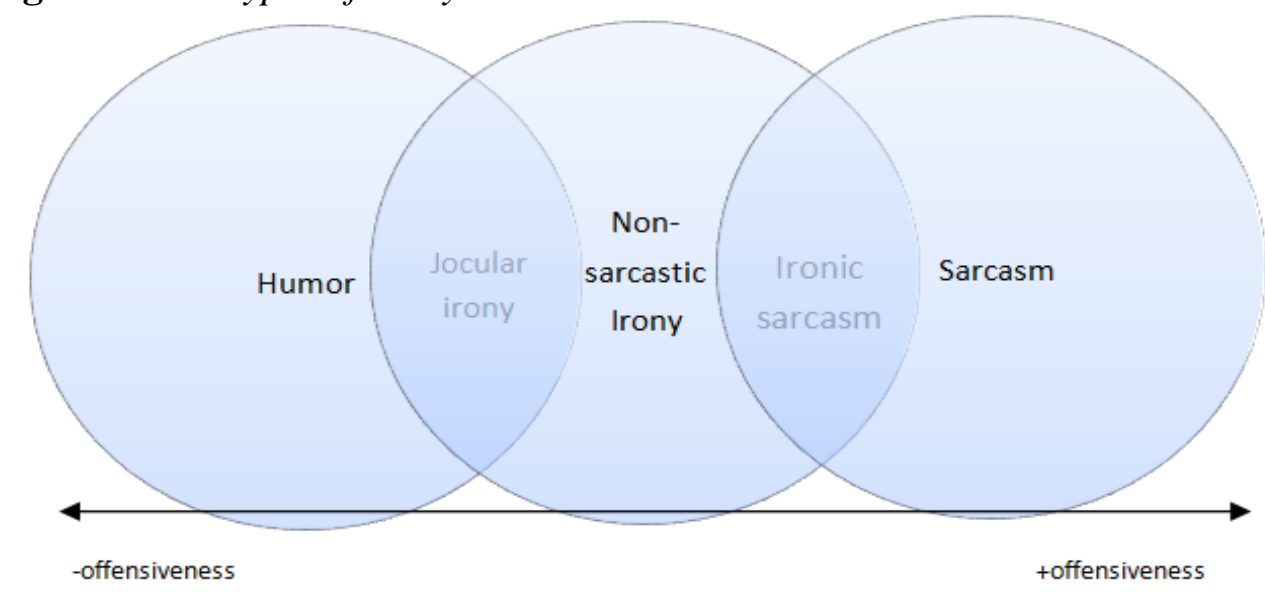

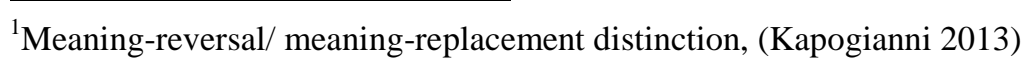


Jocular irony is the affectionate type of irony which does not criticize but expresses positive attitudes (Groeben \& Scheele 1984,p.157,159,230,244, reproduced in Dressler \& Barbaresi 1994,p.357-8; Groeben et al. 1985,p.10). Non-sarcastic-irony "express[es] either negative or positive attitudes, but in neither case is intended to hurt or insult any particular person" (KumonNakamura et al 2007,p.93). Ironic sarcasm "expresses a negative attitude as well as to insult or hurt to some degree" (Kumon-Nakamura et al 2007,p.93). Sarcasm (non-ironic) is considered the highest degree of caustic criticism according to Kapogianni (2013,p.36) as demonstrated in the example (2) below:

2. Context: It is exam period but John is not studying, ignoring his mother's warnings that he is going to fail. After he fails the test, he is obviously disappointed and his mother says:

"So, you are regretting it now, aren't you?"

(Muecke 1970,p. 55; Kapogianni 2013,p.36)

Sarcasm must not be confused with Culpeper's use of the term sarcasm to describe his impoliteness strategy: mock politeness (Culpeper 1996,p.356; Culpeper et al 2003, p.1555; Culpeper 2005,p.42). For Culpeper, mock politeness is an impoliteness strategy which is not very distant from B\&L's notion of off-record politeness. According to this strategy, "the FTA is performed with the use of politeness strategies that are obviously insincere" (Culpeper 1996,p.356), and thus remain polite only on the surface. Mock politeness is therefore used by Culpeper interchangeably with sarcasm, which he considers as an umbrella term for all cases of irony. In the present study, sarcasm is used to describe the most offensive types of irony as in Figure 2. Mock-politeness, however, is used in the section under the heading Strength of Criticism: How Much Does Irony Hurt?, to describe the face aggravating effect of irony in cases of (un)equal power relationships.

In Figure 2, the several types of irony are located in a continuum with two ends of different degrees of offensiveness. The left end depicts the types of irony, which do not always convey criticism but express a positive attitude, such as jocular irony and non-sarcastic irony. Towards the right end of the continuum, we find the types of irony which intend to hurt, such as sarcasm and ironic sarcasm. The borderline between politeness and impoliteness is not explicit because we can hardly say if some types of irony are genuinely impolite or polite and this fact makes irony a tricky case.

\section{Positive \& Negative Irony}

There is an interesting sub-categorization of irony which I would like to refer to, that of negative and positive irony (Myers Roy 1977; Haverkate 1990,p.90; Colston \& Gibbs 2007,p.11-2; Dews, Kaplan \& Winner 2007,p.298; Attardo, 2013,p.44). Positive irony is about assertions which carry 
a negative evaluation at sentence level but imply a positive one at the pragmatic level such as in (3):

3. I hated the food (said in front of an empty plate to praise the cook).

On the contrary, negative irony deals with assertions which convey positive evaluations at sentence level but imply criticism:

4. What a lovely dress (regarding a distinctly unlovely dress).

Positive irony is less frequent than negative irony, because positive irony involves a sentence of negative grammatical construction (example 3) in order to praise. Therefore, positive irony is obviously more "socially dangerous" because in cases where irony fails to be recognized, then one is taken as having said something negative (Myers Roy 1977; Haverkate 1990,p.90; Attardo 2013,p.44). Finally, only negative irony is part of this study because it implies criticism and has an impolite perlocutionary effect $^{1}$ on the addressee as opposed to positive irony that is used to praise.

\section{Irony \& Off-record Indirectness}

As explained in the Literature Review, irony balances between politeness and impoliteness with each of its sub-types, e.g. jocular irony, non-sarcastic irony, ironic sarcasm and sarcasm, located in a continuum with an increasing degree of offensiveness towards sarcasm. The borderlines between the different sub-types of irony are not clearly defined (Figure 2), not allowing the interlocutor to clearly distinguish where one type ends and where the other begins. Figure 2 helps us visualize the fine line between politeness and impoliteness when it comes to the use of irony. The overlapping areas between politeness and impoliteness, led me to explore the abilities of irony by using a politeness theory, that of Brown \& Levinson's (henceforth B\&L) (1987). B\&L's politeness theory will provide the basis for the argumentation of the claim that irony has also a face-aggravating function in the section under the heading 'Strength of Criticism: How Much Does Irony Hurt?' Before I go about exploring the different abilities of irony, I will give the basic views of B\&L on irony.

To begin with, B\&L expand on Goffman's, (1967) notion of face and introduce negative and positive face by talking about acts that intrinsically threaten the speaker's and/ or hearer's face. They define negative face as "the want of every 'competent adult member' that his actions be unimpeded by others" (1987,p.62). Positive face is defined as "the want of every member that his wants be desirable to at least some others" $(1987, p .62)$ and is the desire of people to be appreciated and be approved of.

They therefore provide five strategies according to the vulnerability of the speaker's or hearer's face. The scale of the estimation of face loss shows that

${ }^{1}$ Perlocutionary effect is the effect a speech act has on the hearer either psychological or by getting him do/ believe something (Austin 1962; Searle 1969) 
the risk of the face loss can be low (top of scale) or great (bottom of scale). The five strategies relate to a different degree of potential face loss. For example the first strategy (without redressive action, or bald on record) relates to the least risk of face loss. At the other end, strategy five (Don't do the FTA) relates to the greatest risk of face loss.

Figure 3. Brown \& Levinson's Politeness Strategies

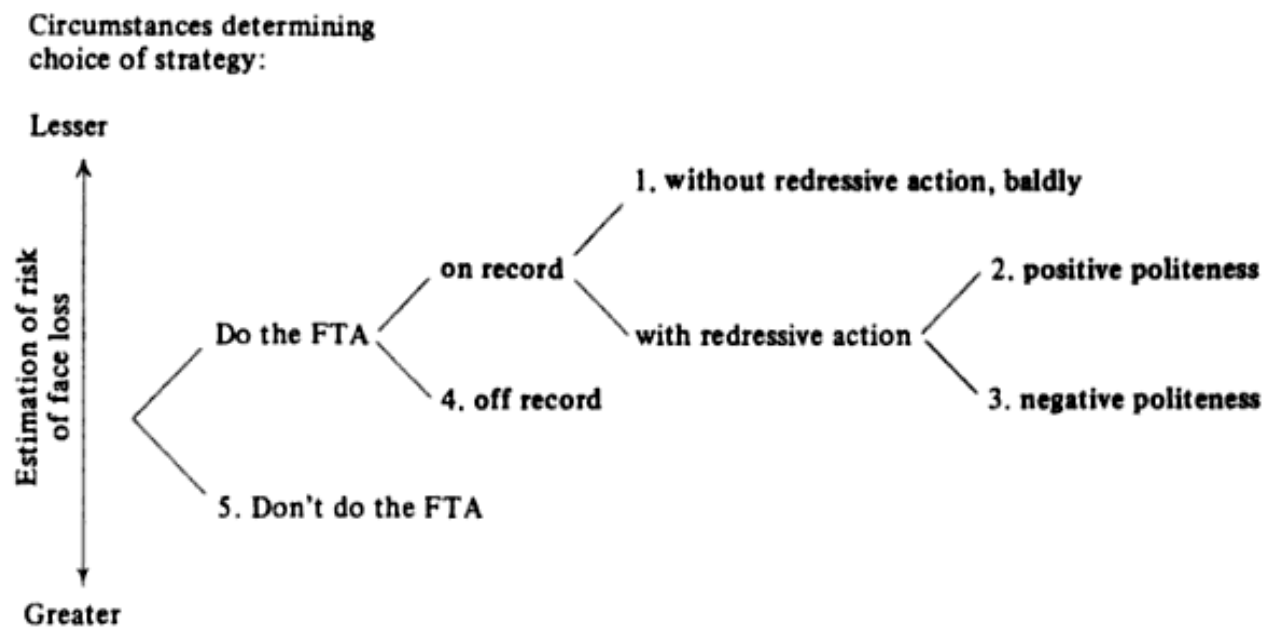

(Brown \& Levinson 1987,p.60)

The choice of the strategy by the speaker is calculable by the formula $\mathrm{W}_{\mathrm{x}}$ $=\mathrm{D}(\mathrm{S}, \mathrm{H})+\mathrm{P}(\mathrm{H}, \mathrm{S})+\mathrm{R}_{\mathrm{x}} \cdot \mathrm{D}(\mathrm{S}, \mathrm{H})$ stands for the social distance between the speaker $(\mathrm{S})$ and the hearer $(\mathrm{H})$ and it represents the "symmetric social dimension of similarity/ difference within which $\mathrm{S}$ and $\mathrm{H}$ stand for the purpose of this act" (1987,p.76). The variable D can be affected by factors such as the frequency of interaction of the interlocutors and their level of intimacy. $\mathrm{P}(\mathrm{H}, \mathrm{S})$ represents the relative power that the hearer has over the speaker. $\mathrm{P}$ reflects an asymmetrical relation, where a hearer can impose "his own plans and his own self-evaluation at the expense of S's plans and self-evaluation" (1987,p.77). Finally, $R_{x}$ is the absolute ranking of imposition in a particular culture and situation. It is calculated by "the degree to which [the impositions] are considered to interfere with an agent's... negative- and positive- face wants" (1987,p.77). The two scales that account for the negative-face FTAs are the ranking of imposition in relation to the expenditure of services and of goods.

According to B\&L $(1987$, p.69, 214, 221), irony is a linguistic realization of the off-record strategy which is used to save face and it is triggered by the violation of the Quality Maxim. The position I argue for in the section under the heading Irony: A Convenient Impoliteness Tool, is that irony is also used as a face-aggravating strategy, depending on the power differences between the interlocutors. 


\section{Irony: A Convenient Impoliteness Tool}

\section{The Case of Over-politeness}

In the title of the present paper irony is described as a tool because it is considered a friendly-like way of being critical and/or offensive (Leech 1983,p. $82,142-4)$. In the same sense, Bayraktaroğlu \& Sifianou (2012) describe the same strategies as the iron fist in the velvet glove, where "speakers use politeness strategies to build up the conversation to a point where they can make an impolite remark". A clear example of the above claim is overpoliteness. There is evidence that over-politeness is usually considered ironic. For example, Kumon-Nakamura et al. ( 2007 , p.57, 78-9, 84) prove that overpolite requests are more likely to be used ironically than under-polite ones because the speaker, by being excessively polite, can insult the hearer/addressee without sounding rude. Therefore, irony can be considered as an off-record impoliteness strategy ( Lachenicht 1980, p.619; Bousfield 2008, p. 83) as in the examples below:

5. Context: Alice and Sarah are in a crowded train; Alice who is obviously able-bodied is sprawled across two seats, and Sarah is standing. Sarah says to Alice:

"I'm curious as to whether it would be physically possible for you to make room for someone else to sit down."

(Weiner 2006, p.128)

6. Would you mind very much if I asked you to consider cleaning up your room sometime this year? (Said by a mother to her child)

(Colston \& Gibbs 2007, p. 5-6)

Examples (5) and (6) are instances of how we can be critical by being over-polite.

Concluding, I propose the property of irony to make criticism without being impolite, as one of the reasons which make people resort to irony instead of choosing a more straightforward way.

\section{Irony as Self-containment}

Another use of irony which explains why people resort to it in order to make criticism and/or be impolite is the fact that it shows self-containment (Dews et al. 2007, p. 300, 314; Tsakona 2011, p.62). Being in control of our emotions is more socially acceptable than verbally attacking someone straightforwardly. This strategy which shows emotional control is cited as one of the social functions of irony in Dews et al. (2007, p. 298) along with humor, status elevation and aggression. As illustrated in the example below, the 
speaker uses irony to express her displeasure about having a door slammed in her face.

7. Context: Two people approach a door. The first person to reach the door opens it and lets it swing shut behind her.

The second person, carrying a heavy box, says:

"Don't hold the door open; I'll just say open sesame"

(Kumon-Nakamura et al. 2007,p.58-9)

\section{Cancellability of Irony}

In the previous subsection (Irony as Self-containment), I explained that irony is a convenient tool to make an impolite remark because it does not make us appear rude or socially inappropriate. In this section, I will propose another reason why people choose irony as a strategy to make criticism rather than using a more straightforward way. This reason is irony's ability to be cancelled at any stage.

As mentioned in the section under the heading Literature Review, I consider irony to be an implicature and I support Grice's stating that implicatures are cancellable (Grice 1989,p. 39,44). The cancellability of irony gives rise to different interpretations and allows the speaker to withdraw from what she said, if the utterance is subsequently considered too bold or inappropriate ( Wilson \& Sperber 1992,p.61; Dews et al. 2007,p. 299; Tsakona 2011,p.62). In the following examples (8) and (9) the speaker can deny her original ironic intent in cases that the hearer is insulted:

8. You sure know a lot (to a know-it-all)

9. Context: Suppose that Alice and Sarah are in a crowded train; Alice, who is obviously able-bodied, is sprawled across two seats, and Sarah is standing. Sarah says to Alice:

Sarah 1: I'm curious as to whether it would be physically possible for you to make room for someone else to sit down.

Sarah 2: Not that you should make room; I'm just curious

(Weiner 2006,p. 128)

More specifically about example (9), (Sarah 2) can explicitly cancel the ironic inplicature of utterance (Sarah 1) (Blome-Tillmann 2008). However, Weiner (2006) claims that the utterance (Sarah 2) might not cancel what was implicated in (Sarah 1), but can be another ironic implicature which is used to imply even more rudely that the hearer should move. I also support the two 
aforementioned claims and reassert my hypothesis that it is the cancellability of irony that makes it so flexible, allowing the speaker to either carry on her ironic implicature during conversation or disassociate herself from the ironic utterance, if it is interpreted as absurd.

Finally, the cancellability of irony allows the speaker to communicate one message to the hearer and a different one to the audience (Dews et al. 2007, p. 313), as in the example below:

10. Context: Said from a student to a professor when the rest of the class is present. All students that attend this particular class (the speaker included) hate the course, but they go because it is obligatory:

"Interesting lecture"

Example (10) could be literally interpreted by the professor, but ironically by the rest of the class.

Overall, examples (8), (9) and (10) show that the cancellability of irony makes it a convenient way to make criticism and/or be impolite because the speaker can deny her ironic intentions at any stage or convey different messages to the recipient and to the audience.

\section{Intentionality of Irony}

This section examines whether the speaker is intentionally trying to create a negative perlocutionary effect on the hearer through ironic criticism or an utterance can be interpreted as ironic even if the speaker did not intend for the utterance to have an impolite effect on the addressee.

So far, there are claims that verbal irony can be either intentional or unintentional ( Gibbs, O’Brien \& Doolittle 1995,p. 187; Attardo 2007,p. 137; Gibbs 2012,p.105,7). More specifically, Attardo (2007,p.137); Gibbs et al. (1995,p.187) and Gibbs (2012,p.105,7) support the idea that irony can be both intentional and unintentional, based on an experiment that is described in Gibbs et al. (1995,p.191-2). The purpose of that experiment was to count the processing time for intentional and unintentional ironic utterances. For this experiment, eighteen pairs of stories were written, each pair ending with the same last line. One story ended with an intentionally ironic comment, whereas the other story ended with the same last line, but with a meaning not intended by the speaker. In the latter cases, the irony arose from the conflict between the situation that the speaker is unaware of and what she actually says. The authors cite only one pair which is reproduced below:

\subsection{Intended irony:}

John and Bill were taking a statistics class together. Before the final exam, they decided to cooperate during the test so they worked out a system so they could secretly share answers. After the exam, John and Bill were really pleased with themselves. They thought they were pretty clever for beating the system. Later that night, a friend 
happened to ask them if they ever tried to cheat. John and Bill looked at each other and laughed, then John said,

"I would never be involved in any cheating"

\subsection{Unintended irony:}

John and Bill were taking a statistics class together. They studied hard together, but John was clearly better prepared than Bill. During the exam, Bill panicked and started to copy answers from John. John did not see Bill do this and so did not know he was actually helping Bill. John took the school's honor code very seriously. Later that night, a friend happened to ask them if they ever tried to cheat. John and Bill looked at each other, then John said,

"I would never be involved in any cheating"

(Gibbs et al. 1995,p.191-2)

At this point, I would like to note that Gibbs et al. example $(11$, ii) is not a successful instance of verbal irony because the speaker is not aware of the contradictory situations that took place and John genuinely believes in the truthfulness of his utterance 'I would never be involved in any cheating'. Therefore, the example (11.2) is better described as an example of dramatic ${ }^{1}$ irony and even better as situational ${ }^{2}$ irony. Taking for granted that the rest of the examples in this experiment are instances of situational irony, then the claim that irony can be both intentional and unintentional is not based on solid evidence. Therefore, this claim can in no way be generalized for verbal irony, let alone ironic criticism.

Furthermore, Haiman $(1990 ; 1998)$ asserts that irony does not require the speaker's intention, whereas sarcasm does. Going one step further from the above distinction, I would suggest that ironic criticism is in most of the cases intentional, if we consider that it is risen by the flouting of Grice's maxims which are by definition intentional:

Flouting a maxim: The intentional and blatant non-observance of a maxim at the level of what is said. This blatancy is overt, that is, it is designed to be noticed by the speaker's interlocutor(s) and is therefore designed to generate a conversational implicature.

(Grice 1975,p.49; 1981,p.85)

\footnotetext{
${ }^{1}$ Dramatic irony happens when the protagonist of a performance utters a sentence that has a clear meaning to the audience but of which the speaker is unaware,

${ }^{2}$ Situational irony is a state of the world which is perceived as ironic (Colston, 2007a, p.97)
} 
It is noteworthy to mention that in the ironic utterances I collected for the present study, there is one example (12) which can be characterized as a fuzzy case between intentionality- unintentionality:

12 Context: The dialogue took place at a Greek University student union meeting. A is a representative of a student party, while B is known by A to be a supporter of an opposing student party. The members of the two opposing parties are often caught in heated debates.

A1: It is unfair for our party's name not to be mentioned in the list of those who contributed to the [discussed] event, given that our members were actively present throughout the course of the preparations [...]

B1: Of course they were!

A2: I will not tolerate any ironies from you.

B2: But I wasn’t being ironic. I was actually supporting your statement.

(Kapogianni 2013,p. 73)

I consider utterance B1 as a fuzzy case between intentionalityunintentionality because it could be both. More specifically, given the cancellability of irony (see previous subsection), interlocutor B could have intended utterance B1 to be ironic, but after the disapproving reaction (A2) of the interlocutor, A could deliberately retreat from the responsibility of having said B1 ironically and let the aggressive reaction (A2) of the interlocutor be considered as a misunderstanding. It is due to the cancellability of irony that we cannot be sure of the speaker's intentions.

The evidence from the existing literature shows that verbal irony can be either intentional or unintentional. My claim is that ironic criticism is in the majority of cases intentional, but for the lack of authentic examples in the present work, the claim should be further quantitatively tested.

\section{Strength of Criticism: How Much Does Irony Hurt?}

In the Literature Review, I defined the different types of irony and proposed Fig. 3.2 where the obscure borders between the sub-types of irony are depicted. The present section is devoted to defending the main claim of this study: that irony is not only a face-saving strategy, as B\&L and other scholars claim (Jorgensen 1996; Dews et al. 2007, p. 297, 300), but also a faceaggravating strategy used to increase the strength of criticism. The opinion that off-record indirectness can be used to enhance the offence is not new but was introduced into other studies as well (Leech 1983, p.160; Colston 2007b, p.303, 324, 333; Kumon-Nakamura, Glucksberg \& Brown 2007, p.71; Bousfield 2008b, p.149; Tsakona 2011, p.62). In what follows, I use examples in English and Greek, both authentic and from existing literature, to show that power 
differences between the interlocutors play a significant role into whether irony increases the strength of criticism or not.

\section{Irony Among Unequals}

B\&L's politeness theory considers irony as a linguistic realization of the off- record indirectness strategy used when the FTA is great to save face. The aforementioned theory links indirectness with politeness, a connection which is not necessarily true as the examples (13-16) demonstrate. Example (13) is indirect as opposed to the direct form in example (14), but it is not necessarily considered more polite, because it carries an ironic tone which implies that the customs official knows that the woman is involved in an illegal activity and it is just a prompt for her to confess.

Context: said from a customs official to a woman:

13 Haven't you something to declare? (Leech 1983, p.160)

14 Do you have anything to declare?

Additionally, example (15) is an indirect way to tell someone that they are stupid and it can be more insulting than the direct example (16) (Culpeper 2011).

15 Do you have sawdust for brains? (Jocular irony)

16 You are stupid

(2011, p.184)

A possible explanation for the negative perlocutionary effect which irony can have on the hearer is the power difference between the interlocutors. I will now use examples with power differences between the interlocutors to explicitly demonstrate the ways the hearer might perceive ironic criticism.

17 Context: Manuel was the star player on the soccer team, but he could not play in the city championship game because he caught the flu and was extremely sick. When the team captain heard about this he said,

"We'll win the championship for sure now."

(Colston 2007b, p.322-3)

The use of the off-record indirectness strategy by the team captain in example (17) is redundant because the relative power $(\mathrm{P})$ of the player (Hearer) over the captain (Speaker) is low, consequently the weight of imposition $\left(\mathrm{W}_{\mathrm{x}}\right)$ is low; so the captain could have chosen a more direct expression according to B\&L's formula (subsection Irony \& Off-record Indirectness). Despite this fact, the strength of the criticism in the utterance 'We'll win the championship for 
sure now' can hurt the hearer's face as much as, and possibly more, than a literal expression such as 'we don't stand a chance'. Here is another example:

18 Context: At a military environment during shift handover said by the superior officer to a subordinate one:

"The genius is taking over"

(Tselika 2014, p.21)

Example (18) is a case of ironic critisism directed from a superior to a subordinate which can be easily considered as insulting, if not discriminating, by the hearer/addressee. The use of the off-record indirectness strategy by the superior in (18) is again uneccessary because the low relative power of the inferior would allow the superior to have chosen a more direct expression. Examples (17) and (18) are cases of mock-politeness (Culpeper 1996,p.356; Culpeper et al 2003,p.1555; Culpeper 2005,p.42) and in these cases irony seems to be used among unequals as exploitative entertainment in order to cause pain to the hearer but pleasure to other participants (Culpeper 1996,p.352; 2011,p.215; Holmes, 2000).

\section{Irony Among Equals}

However, if the utterance in example (18) was said between friends, then the risk of the hearer's face loss might not have been the same, such as in examples (19-21) which are said among equals:

19 Context: Sebastian did not regularly attend his classes, and when he did he was always disruptive. He stormed into class for the first time in a month. His friend/someone turned to him and said the following:

"It's always so nice to have you in class."

(Dews et al. 2007,p.304)

20 Context: Conversation between two students in a college dormitory.

Male Student: So where were you before Cambridge?

Female Student: In Leeds. I guess you should have studied there if you are supposed to wear one of these. (showing her college hoody with the logo of University of Leeds on it)

21 Context: conversation between two students at a café.

A: Oh I've just finished my essay on Syntax, I can email it to you if you wanna read it. 
B: Yea, why not. I will buy myself some coffee.

Examples (19-21) can be considered as examples of jocular irony, which are used among equals as mock-politeness to increase solidarity and promote intimacy (Culpeper 1996, p.352; 2011, p.215; Holmes 2000), and is the opposite case from examples (17) and (18) which are used as as a form of oppression by the higher-status interlocutor to the lower status one.

Overall, examples (17) and (18) are ironic utterances which are addressed between interlocutors of unequal status. The speakers use irony even if the context of conversation allows for a more direct strategy. This fact comes into opposition with B\&L's prediction that irony is reserved for cases where the seriousness of the FTA is great (Brown \& Levinson 1987,p.265). Whereas in examples (19-21) irony is used among equals in a jocular manner to increase solidarity and promote intimacy. We therefore conclude that interlocutors' power differences can have a significant effect on the face loss which the ironic utterance has on the speaker. More specifically, it seems that when the irony is directed from the more powerful to the less powerful, then criticism has a negative perlocutionary effect on the hearer than literal criticism, even in cases of jocular irony. In the following section, I elaborate more extensively on instances of language adressed from superiors to inferiors in a military environment to show the link of irony with mock-politeness.

\section{Going 'Downwards'}

A cross-cultural study conducted on the politeness phenomena in military environments (Tselika 2014) reveals that in cases where irony is used from superordinate officers to subordinate ones, there is a negative perlocutionary effect on the latter. The evidence in the subsection under the heading Irony Among Unequals, allows assumptions that in unequal conversations and when the ironic utterance is addressed to a person of lower status, irony tends to be a face-aggravating strategy and not a face-saving one as B\&L (1987) initially claimed. Accordinglly, when irony is used by a superior to an inferior in a military context, then it tends to have a negative perlocutionary effect, because it could be used as a means of power exercise and imposition. To support this claim, I name the conversations addressed from superior to inferior officers as "downwards", resembling the downward chain of command found in military environments. The examples used are from the existing literature and authentic drawn from a Greek air force environment.

To begin with, when irony is used 'downwards' in a military context, its use is not polite but mock-polite. Mock-politeness is used to perform the FTA by the use of a politeness strategy while remaining polite only on the surface (Culpeper, 1996,p.356; Culpeper et al 2003,p.1555; Culpeper 2005,p.42), as in the example (22) below: 
22 Context: Following his unsatisfactory showing at the morning's barrack room inspection, Private Baxter (S1) has an appointment with the Company Sergeant Major (S2) who is reprimanding S1 about his failure to get a haircut.

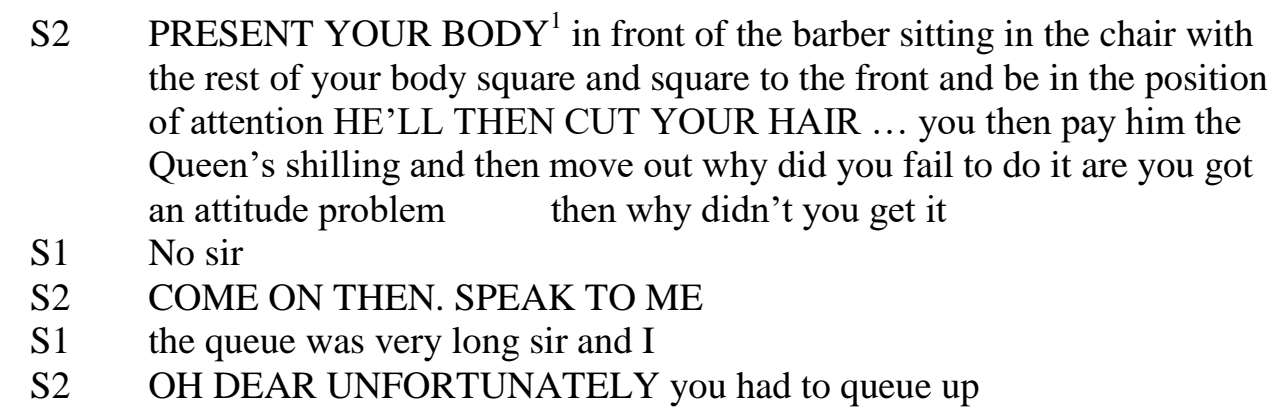
the rest of your body square and square to the front and be in the position of attention HE'LL THEN CUT YOUR HAIR ... you then pay him the Queen's shilling and then move out why did you fail to do it are you got an attitude problem then why didn't you get it

S1 No sir

S2 COME ON THEN. SPEAK TO ME

S1 the queue was very long sir and I

S2 OH DEAR UNFORTUNATELY you had to queue up

(Bousfield 2008a,p.119 taken from Redcaps, extract 53)

The Company Sergeant Major in example (22) uses irony in line 9 to appear mock-polite in order to ridicule the Private for not standing in the queue to have a haircut. If we take into consideration that in-group relations in the military show a preference for directness over indirectness, as the latter might appear pretentious (Tselika 2014), then there is a great possibility that irony can hurt more than direct criticism.

Furthermore, Leech (1983) describes irony as a "friendly way of being offensive" (1983, p.144); irony can be therefore used as a tool for making criticism without appearing impolite but still enhancing the force of criticism (Colston 2007b,p.303,324,333; Kumon-Nakamura et al. 2007,p.71; Tsakona 2011,p.62 \& Lachenicht 1980) as in example (23).

23 The lieutenant (O’Neill) stated her opinion about an ongoing operation. Her superior (Royce) disapproves of the fact that she expressed her opinion even though she was right:

1 Royce The last time I checked, lieutenant, you were an analyst not an

2 operation specialist

3 (long pause)

4 Royce Good work lieutenant

5 O'Neill Thank you sir, it was good to get involved and do some good

6 Royce Now the problem is intel officers shouldn't get involved, you

7 monitor, analyze.

8 You need to know the fine art of detachment lieutenant

J. I. Jane by R.Scott, 1997

\footnotetext{
${ }^{1}$ Upper case indicates shouting voice
} 
In example (23), the superior (Royce) uses irony throughout the conversation (lines 1,2,4,7 and 8) to express his disapproval of his inferior expressing her opinion. In example (24) below the Colonel makes a critical comment about an inferior officer's absence.

24 Context: the Colonel is criticizing his inferior's (Mr Papadopoulos ${ }^{1}$ ) absence from the briefing

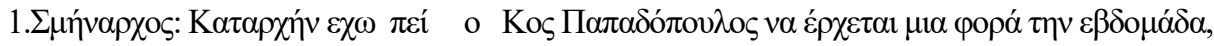

1. Col: Initially have said the Mr. Papadopoulos to come one time the week,

1. Col: Before we start, I have said that I want Mr. Papadopoulos here once a week,

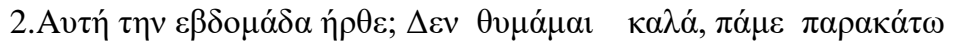

2.This the week came? Not remember well, move on

2.Has he been here this week? I don't remember well, let's move on

(Tselika 2014,p.79)

In example (24), the Colonel uses irony (line 2) to state that this week the inferior did not attend the briefing. Although he remembers correctly, he

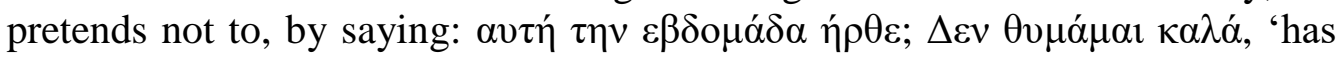
he been here this week? I don't remember well'. Then he abruptly changes the subject of the discussion by saying $\pi \alpha ́ \mu \varepsilon \pi \alpha \rho \alpha \kappa \alpha ́ \tau \omega$ 'let's move on'.

In authentic example (25), the superior officer in line 3 is criticizing the inferior's reply (line 2) by the use of irony, instead of saying directly that reply (2) is actually redundant, since everyone knows that there is only one person

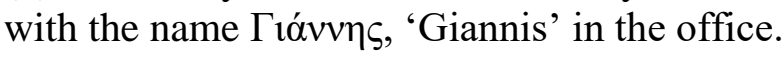

25 Context: Telephone conversation between two officers

(Summons: phone ring)

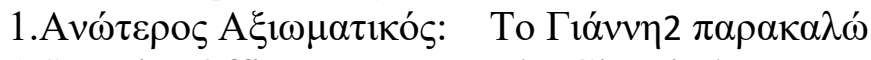

1.Superior Officer:

The Gianni please

1. Superior Officer: John please

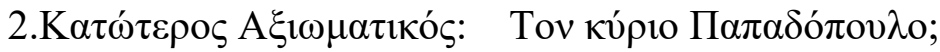

2.Inferior Officer:

The mister Papadopoulos?

2.Inferior Officer:

(Do you mean) Mr. Papadopoulos?

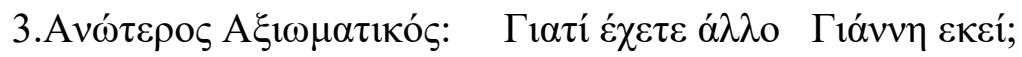

3.Superior Officer:

3.Superior Officer:

Why have other Gianni there?

Do you have any other John there?

To sum up, the ranking difference between the officers in military environments provide an appropriate context to study how the interlocutors'

\footnotetext{
${ }^{1}$ The names are fictional to preserve anonymity

${ }^{2}$ The names are fictional to preserve anonymity
} 
power discrepancies mould the language which is used. As far as irony is concerned, the choice of off-record indirectness by superior officers, when they address inferior officers, is unnecessary as predicted by B\&L's politeness, because a more direct strategy would appear more appropriate for the high rank of the speaker. When irony is used from someone with greater status to someone with less one, then irony has a face-aggravating effect and its use resembles Culpeper's description of mock-politeness (Culpeper 1996,p.356; Culpeper et al 2003,p.1555; Culpeper 2005,p.42). Finally, when irony is used among equals as a mock-politeness, then its function remains face-saving as B\&L initially described.

\section{Limitations of Present Study}

The present paper is theoretically approaching the abilities of irony, exploring its impolite functions by the use of examples, most of them taken from the existing literature. The methodology followed in this paper poses its first limitation which is the lack of plethora of authentic examples. The scarcity of ironic instances in conversations and the ethical issues raised by observing real life conversations, especially in military environments, are the two primary reasons for the lack of authentic examples in the present study. The claims which are made in this paper should be further quantitatively examined against a corpus of authentic ironic conversations for their validity.

The paper's second limitation is that the intended meaning of the ironic examples and the subsequent effect on the hearer are subjectively interpreted by the author. Reliable interpretations of the intended meaning of ironic utterances, as also judgments about the degree of offence, should be further investigated by measuring the reaction of native-speakers and their judgment on the degree of offence which each utterance bears ${ }^{1}$.

\section{Conclusion}

Irony balances between politeness and impoliteness with its different subtypes being defined and discerned rather difficultly and carrying a different degree of offensiveness. One of irony's attributes which makes it a convenient way for someone to be impolite, is the connection of over-politeness with impoliteness. Excessive politeness bears an ironic tone and is usually judged as incencere by the hearer but allows the speaker to make an impolite remark without appearing socially inappropriate (subsection The Case of Overpoliteness).

Social appropriacy is the second trait of irony which allows people to make criticism without attacking someone straightforwardly and therefore appearing rude (subsection Irony as Self-containment). The cancellability of

${ }^{1}$ I would like to thank an anonymous reviewer for suggesting acceptability judgment tests as a method of analysis of ironic examples. 
irony allows initially the speaker to cancel the utterance communicated according to the reaction of the speaker or the audience (subsection Cancellability of Irony) and deny her ironic intention; and secondly, to communicate one message to the hearer and another to the audience.

Along with the cancellability of irony goes its intentionality (subsection Intentionality of Irony). The speaker can easily withdraw from what is said because her real intentions are not always clear. Previous studies on the intentionality of irony point towards both directions, but if we take Crice's claim that implicatures are by definition intentional, then we can only assume that irony is usually intentional. The cases where the ironic intentions of the speaker are doubtful can be cancelled, if the message is considered too bold for the occasion.

The instances of irony which are used to criticise resemble Culpeper's impoliteness strategy: mock politeness (Culpeper 1996,p.356; Culpeper et al 2003,p.1555; Culpeper 2005,p.42). The effect which irony has on the hearer seems to be related with the power differences between the interlocutors. In cases of equal relationships, irony is used as mock-politeness for jocular purposes and its function is face-saving (subsection Irony Among Equals). In cases of unequal relationships, as the data from military context disclose (subsection Going 'Downwards'), irony is used as mock-politeness to enhance the strenth of criticism with a negative perlocutionary effect on the hearer.

Finally, the areas of the present paper which need further consideration are the clear definition of borders between the sub-type of irony and the examination of the degree of offence which each sub-type bears. As also, the claims which are made in the present study should be quantitatively tested against a corpus of ironic instances of language taken from interlocutors with power differences.

\section{Acknowledgments}

I would like to thank Prof. Kasia Jaszczolt whose inspiring teaching and guidance led me to the conception of the above ideas during my Master studies at the University of Cambridge.

\section{References}

Attardo, S., 2007. Irony As Relevant Inappropriateness. In H. L. Gibbs Jr., R.W., Colston, ed. Irony in Language and Thought: A Cognitive Science Reader. New York: Lawrence Erlbaum, pp. 135-172.

Attardo, S., 2013. Intentionality and Irony. In M. B. A. Gurillo, L.R., Ortega, ed. Irony and Humor. John Benjamins, pp. 39-58.

Austin, J.L., 1962. How To Do Things With Words, Oxford University Press.

Bayraktaroğlu, A. \& Sifianou, M., 2012. The iron fist in a velvet glove: How politeness can contribute to impoliteness. Journal of Politeness Research, 8(2012), pp.143-160. 
Blome-Tillmann, M. \& Weiner, M., 2008. Conversational implicature and the cancellability test. Analysis, 68(April), pp.156-160.

Bousfield, D., 2008a. Impoliteness in Interaction, John Benjamins Publishing.

Bousfield, D., 2008b. Impoliteness in the struggle for power. In D. Bousfield \& M. A. Locher, eds. Impoliteness in Language: Studies on Its Interplay with Power in Theory and Practice. Mouton de Gruyter, pp. 127-54.

Brown, P., Levinson, S.C., 1987. Politeness: Some Universals in Language Usage, Cambridge University Press.

Clark, H.H., Gerrig, R.J., 2007. On the Pretense Theory of Irony. In H. L. Gibbs Jr., R.W., Colston, ed. Irony in Language and Thought: A Cognitive Science Reader. New York: Lawrence Erlbaum, pp. 25-34.

Colston, H.L., 2007a. On Necessary Conditions for Verbal Irony Comprehension. In H. L. Gibbs Jr., R.W., Colston, ed. Irony in Language and Thought: A Cognitive Science Reader. New York: Lawrence Erlbaum, pp. 97-134.

Colston, H.L., 2007b. Salting a Wound or Sugaring a Pill: The Pragmatic Functions of Ironic Criticism. In H. L. Gibbs Jr., R.W., Colston, ed. Irony in Language and Thought: A Cognitive Science Reader. New York: Lawrence Erlbaum, pp. 319338.

Colston, H.L., Gibbs Jr., R.W., 2007. A Brief History of Irony. In H. L. Gibbs Jr., R.W., Colston, ed. Irony in Language and Thought: A Cognitive Science Reader. New York: Lawrence Erlbaum, pp. 3-24.

Culpeper, J., 1996. Towards an anatomy of impoliteness. Journal of Pragmatics, 25, pp.349-367.

Culpeper, J., Bousfield, D. \& Wichmann, A., 2003. Impoliteness revisited: with special reference to dynamic and prosodic aspects. Journal of Pragmatics, 35, pp.1545-1579.

Culpeper, J., 2005. Impoliteness and Entertainment in the Television Quiz Show: The Weakest Link. Journal of Politeness Research. Language, Behaviour, Culture, $1(1)$, pp.35-72.

Culpeper, J., 2011. Impoliteness: Using Language to Cause Offence, Cambridge University Press.

Dews, S., Kaplan, J., Winner, E., 2007. Why Not Say It Directly? The Social Functions of Irony. In H. L. Gibbs Jr., R. W., Colston, ed. Irony in Language and Thought: A Cognitive Science Reader. New York: Lawrence Erlbaum, pp. 297318.

Dressler, W.U. \& Barbaresi, L.M., 1994. Morphopragmatics: Diminutives and Intensifiers in Italian, German, and Other Languages, Walter de Gruyter.

Gibbs, R.W., O’Brien, J.E. \& Doolittle, S., 1995. Inferring meanings that are not intended: Speakers' intentions and irony comprehension. Discourse Processes, 20(2), pp.187-203.

Gibbs, R.W., 2012. Are ironic acts deliberate? Journal of Pragmatics, 44(1), pp.104115.

Goffman, E., 1967. Interaction Rituals: Essays on Face-to-Face Behavior, Pantheon Books, New York.

Grice, H.P., 1975. Logic and conversation. In J. L. Cole, P. Morgan, ed. Syntax and Semantics, Volume 3: Speech acts. New York: Academic, pp. 41-58.

Grice, H.P., 1981. Presupposition and Conversational Implicature. In P. Cole, ed. Radical Pragmatics. New York: Academic Press, pp. 183 - 198.

Grice, P., 1989. Studies in the Way of Words, Cambridge: MA:Harvard University Press. 
Groeben, N. \& Scheele, B., 1984. Produktion und rezeption von ironie I. In Pragmalinguistische Beschreibung und psycholinguistische Erklärungshypothesen. Tübingen: Niemeyer.

Groeben, N., Hanne, S. \& Drinkmann, A., 1985. Produktion und rezeption von ironie II. In Empirische Untersuchungen zu Bedingungen und Wirkungen ironischer Sprechakte. Tübingen: Niemeyer.

Haiman, J., 1990. Sarcasm as Theatre. Cognitive Linguistics, 1, pp.181-205.

Haiman, J., 1998. Talk is Cheap: Sarcasm, Alienation, and the Evolution of Language, UK: Oxford University Press.

Haverkate, H., 1990. A speech act analysis of irony. Journal of Pragmatics, 14, pp.77-109.

Holmes, J., 2000. Politeness, power and provocation: How humour functions in the workplace. Discourse Studies, 2(2), pp.159-85.

Jorgensen, J., 1996. The functions of sarcastic irony in speech. Journal of Pragmatics* 26(5), pp.613-634.

Kapogianni, E., 2013. Irony and the Literal Versus Nonliteral Distinction. $\mathrm{PhD}$ Thesis. University of Cambridge.

Kumon-Nakamura, S., Glucksberg, S., Brown, M., 2007. How About Another Piece of Pie: The Allusional Pretense Theory of Discourse Irony. In H. L. Gibbs Jr., R.W., Colston, ed. Irony in Language and Thought: A Cognitive Science Reader. New York: Lawrence Erlbaum, pp. 57-96.

Lachenicht, L.G., 1980. Aggravating Language: A Study of Abusive and Insulting Language. Papers in Linguistics: International Journal of Human Communication, 13(4), pp.607-688.

Leech, G.N., 1983. Principles of Pragmatics, Longman.

Muecke, D.C., 1970. Irony, Methuen \& Company.

Myers Roy, A., 1977. Towards a Definition of Irony. In R. Fasold, R.W., Shuy, ed. Studies in Language Variation. Washington, D.C.:Georgetown University Press, pp. 171-183.

Scott, R., 1997. J.I.Jane

Searle, J.R., 1969. Speech Acts, Cambridge: Cambridge University Press.

Sperber, D., Wilson, D., 1981. Irony and the Use-mention Distinction. In P. Cole, ed. Radical Pragmatics. New York-London: Academic Press, pp. 295-318.

Tsakona, V., 2011. Irony beyond criticism: Evidence from Greek parliamentary discourse. Pragmatics and Society, 2(1), pp.57-86.

Tselika, A., 2014. The Limits of the Applicability of a Strategic Approach to Politeness with reference to Military Discourse. MPhil Thesis. University of Cambridge. Available at: https://drive.google.com/file/d/0B0kmd QITQUdQVN oWGt4ZkRId2M/view? usp=sharing 